\title{
HUBUNGAN KARAKTERISTIK IBU HAMIL DENGAN KLASIFIKASI PRE EKLAMSIA DI BEKASI
}

\author{
Sion Gloria Pardede ${ }^{1}$, Justina Purwarini ${ }^{2}$, Sada Rasmada ${ }^{3}$ \\ ${ }^{1,2,3}$ Program Studi S1 Keperawatan STIK Sint Carolus Jakarta \\ Email: justinearini@gmail.com
}

\begin{abstract}
Pre-eclampsia is a collection of symptoms such as hypertension, edema and proteinuria in pregnant, childbirth and postpartum women that occur at 20 weeks of gestation until the end of the first week after delivery. Pre-eclampsia can adversely affect the mother and fetus, such as fetal distress and even death due to lack of oxygenation. Maternal mortality rate (MMR) which occurs where one of the causes is pre-eclampsia. This study aims to determine the relationship between the characteristics of pregnant women (maternal age, parity, education, occupation and history of hypertension) to the classification of pre-eclampsia. Quantitative descriptive research design, with a total sampling of 73 pregnant women patient respondents at the East Bekasi Private Hospital in 2018-2019 who experienced pre-eclampsia. It was found that the results of the classification of respondents were mostly mild pre-eclampsia. Theanalysis used chi square with the conclusion that there is a relationship between the age of pregnant women and the classification of pre-eclampsia (P value 0.000), parity ( $P$ value 0.023$)$, history of hypertension ( $P$ value 0.000). There is no relationship between education (Pvalue 0.667) and work ( $P$ value 0.624). This research is expected to be a reference in order toimprove service to patients, especially in conducting assessments on pregnant women. Where maternal age, parity and history of hypertension have a relationship with the classification of preeclmasia in pregnant women.
\end{abstract}

Keywords: Characteristics, Pre-Eclampsia, Classification

\section{PENDAHULUAN}

Angka Kematian Ibu (AKI) merupakan salah satu indikator yang penting untuk menggambarkan kesejahteraan masyarakat disuatu negara dalam pembangunan dibidang kesehatan yang mengacu pada jumlah kematian ibu terkait dengan masalah kehamilan, persalinan dan nifas (WHO, 2014). Kematian ibu menurut definisi WHO-SEARO (1998) adalah kematian perempuan selama masa kehamilan atau dalam periode 42 hari setelah persalinan, terlepas dari lama dan letak kehamilan, dan akibat dari semua sebab terkait dengan atau diperberat oleh kehamilan atau penangganannya, tetapi kematian yang dimaksud ini bukanlah disebabkan oleh kecelakaan/cedera (Sirait, 2012).

Masalah kesehatan yang menjadi penyebab angka kematian ibu (AKI) salah satunya adalah Pre-eklamsia. Menurut Manuaba dalam buku Sukarni dan Wahyu (2013), Pre-eklamsia (toksemia gravidarum) adalah tekanan darah tinggi atau hipertensi yang disertai dengan proteinuria (protein dalam air kemih) atau adanya edema (penimbunan cairan), yang terjadi pada kehamilan 20 minggu sampai akhir minggu pertama setelah persalinan.Pre eklamsia merupakan salah satu gangguan hipertensi kehamilan yang ditandai dengan disfungsi endotel, tekanan darah tinggi, dan proteinuria yang timbul pada paruh kedua kehamilan, tetapi definisi yang tepat

DOI : https://doi.org/10.51544/jmn.v4i2.1796

(C) 2021 Jurnal Mutiara Ners. This is an open accessarticleunder the CC BY-SA license Website : http://e-journal.sari-mutiara.ac.id/index.php/NERS/index 
dan kriteria diagnostik tetap menjadi subjek perdebatan (Purde et al, 2015).

Pre-eklamsia memberikan pengaruh dalam kehamilan sebesar 3\% sampai $8 \%$ di seluruh dunia. WHO mencatat terdapat 500.000 atau lebih wanita di dunia meninggal setiap tahunnya, dan negara Afrika juga Asia dengan prosentase $95 \%$ wanita meninggal diakibatkan oleh komplikasi kehamilan.

Penyebab preeklamsia secara pasti belum diketahui secara pasti, namun beberapa faktor yang kemungkinan dapat mempengaruhi kejadian preeklamsia yaitu paritas dimana wanita multigravida memiliki risiko lebih besar (7-10\%). Faktor risiko lainnya riwayat hipertensi kronis, usia ibu lebih dari 35 tahun, berat ibu yang berlebih, dan etnis Amerika Afrika. (Kenneth Leveno, 2015).

Peningkatan angka kejadian pre eklamsia yang cenderung meningkat akan memberi dampak pada peningkatan angka kematian ibu dan juga janin. Di RS swasta Bekasi Timur didapatkan dalam setahun terakhir didapatkan 39 pasien rawat inap karena pre eklamsi dan dari kondisi pre eklamsia tersebut memberikan dampak terjadinya kelahiran prematur pada 17 ibu hamil.

Data tersebut dapat digunakan untuk menentukan tindakanpencegahan serta intervensi yang tepat bagi pasien dengan pre-eklamsia sehingga angka kematian ibu dan angka kematian janin dapat menurun. Penelitian ini bertujuan untuk mengetahui hubungan karakteristik ibu dengan kejadian preeklamsi di RS Bekasi. Diharapkan peran perawat dalam memberikan intervensi yang tepat dengan melihat factor-faktor yang berhubungan dengan kondisi pre eklamsi sehingga dapat membantu pasien untuk meningkatkan kondisi kesehatannya.

\section{METODE PENELITIAN}

Penelitian ini merupakanpenelitian kuantitatif retrospektif dengan cara mengambil data sekunder pasien dari rekam medis periode 2018

- 2019, dengan desain cross sectional. Populasi dalam Penelitian ini adalah data dalam Rekam Medis ibu hamil dengan Pre-eklamsia yang berkunjung di RS Swasta Bekasi Timur tahun 2018 - 2019 sebanyak 73 responden. Tehnik pengambilan sampel atau sampling yang digunakan adalah total sampling, sebanyak 73 responden. Penelitian dilakukan di RS "Y" Bekasi.

Instrumen yang digunakan pada penelitian ini adalah formulir observasi, formulir-formulir lain yang berkaitan dengan pencatatan data Rekam Medis pasien ibu hamil yang terdiagnosa Preeklamsia di RS Bekasi Timur. Formulir data penelitian ini berisi identitas pasien meliputi tanggal lahir, usia ibu, paritas, pendidikan, pekerjaan, riwayat hipertensi dan klasifikasi preeklamsia. Analisis data digunakan analisisi univariat dan bivariat. Analisa univariat untuk mengetahui distribusi frekuensi dan presentasi hasil data karakteristik responden seperti usia ibu, paritas, pendidikan, pekerjaan, riwayat hipertensi dan klasifikasi pre eklamsia. Analisis bivariat untuk mengetahui hubungan karakteristik ibu hamil terhadap klasifikasi pre eklamsia dengan menggunakan analisis uji $C h i$ Square. 


\section{HASIL}

Tabel 1. Distribusi Frekuensi Karakteristik Responden

\begin{tabular}{ccc}
$\begin{array}{c}\text { Karakteristik } \\
\text { Responden }\end{array}$ & N & $\%$ \\
\cline { 1 - 2 } Usia & & \\
$\begin{array}{c}\text { Tidak } \\
\text { Berisiko }\end{array}$ & 53 & 72.6 \\
Berisiko & 20 & 27.4 \\
\hline Paritas & & \\
\hline Primigravida & 30 & 41.1 \\
Multigravida & 43 & 58.9 \\
\hline Pendidikan & & \\
\hline Rendah & 31 & 42.5 \\
Tinggi & 42 & 57.5 \\
\hline Pekerjaan & & \\
\hline Tidak & 35 & 47.9 \\
bekerja & & \\
Bekerja & 38 & 52.1 \\
\hline Riwayat Hypertensi & & \\
\hline Tidak & 41 & 56.2 \\
Ya & 32 & 43.8 \\
\hline Total & 73 & 100 \\
\hline
\end{tabular}

Berdasarkan tabel 1 diketahui bahwa sebagian besar responden berada pada rentang usia tidak beresiko 20-35 tahun sebanyak 53 responden $(72,6 \%)$, status paritas multigravida sebanyak 43 responden $(58,9 \%)$, berpendidikan tinggi sebanyak 42 responden $(57,5 \%)$, status bekerja sebanyak 38 responden $(52,1 \%)$, dan sebanyak 41 responden $(56,2 \%)$ merupakan ibu yang tidak memiliki riwayat hipertensi sebelumnya.

Tabel 2. Distribusi Frekuensi Klasifikasi Pre eklamsia

\begin{tabular}{ccc}
$\begin{array}{ccc}\text { Klasifikasi Pre } \\
\text { Eklamsia }\end{array}$ & $\mathbf{N}$ & $\%$ \\
$\begin{array}{c}\text { Pre } \\
\text { EklamsiaRingan }\end{array}$ & 50 & 68,5 \\
$\begin{array}{c}\text { Pre } \\
\text { EklamsiaBerat }\end{array}$ & 23 & 31,5 \\
\hline Total & $\underline{73}$ & $\underline{100}$ \\
\hline
\end{tabular}

Berdasarkan tabel 2 didapatkan data bahwa sebagian besar responden mengalami pre eklamsia ringan dengan jumlah 50 responden $(68,5 \%)$ sedangkan 23 responde lainnya $(31,5 \%)$ mengalami pre eklamsia berat.

Tabel 3. Hubungan Karakteristik Ibu Hamil Dengan Klasifikasi Preeklamsia di RS "Y" Bekasi

\begin{tabular}{|c|c|c|c|c|c|c|c|c|}
\hline \multirow{3}{*}{ Variabel } & \multicolumn{4}{|c|}{ Klasifikasi Pre Eklamsia } & \multirow{2}{*}{\multicolumn{2}{|c|}{ Total }} & \multirow{3}{*}{$\begin{array}{c}P \\
\text { Value }\end{array}$} & \multirow{3}{*}{$\begin{array}{c}\text { OR } \\
(\min -\max )\end{array}$} \\
\hline & \multicolumn{2}{|c|}{ PER } & \multicolumn{2}{|c|}{ PEB } & & & & \\
\hline & $\mathbf{N}$ & $\%$ & $\mathbf{N}$ & $\%$ & $\mathbf{N}$ & $\%$ & & \\
\hline Usia & & & & & & & \multirow{3}{*}{0,000} & \multirow{3}{*}{$\begin{array}{c}44,3 \\
(9,9-197,5)\end{array}$} \\
\hline TidakBeresiko & 47 & 88,7 & 6 & 11,3 & 53 & 100 & & \\
\hline Beresiko & 3 & 15 & 17 & 85 & 20 & 100 & & \\
\hline \multicolumn{9}{|l|}{ Paritas } \\
\hline Primigravida & 25 & 83,3 & 5 & 16,7 & 30 & 100 & \multirow{2}{*}{0,023} & \\
\hline Multigravida & 25 & 58,1 & 18 & 41,9 & 43 & 100 & & $(1,1-11,2)$ \\
\hline \multicolumn{9}{|l|}{ Pendidikan } \\
\hline Rendah & 21 & 67,7 & 10 & 32,3 & 31 & 100 & \multirow[t]{2}{*}{0,906} & \\
\hline Tinggi & 29 & 69 & 13 & 31 & 42 & 100 & & \\
\hline \multicolumn{9}{|l|}{ Pekerjaan } \\
\hline TidakBekerja & 23 & 65,7 & 12 & 34,3 & 35 & 100 & \multirow[t]{2}{*}{0,624} & \\
\hline Bekerja & 27 & 71,1 & 11 & 28,9 & 38 & 100 & & \\
\hline \multicolumn{9}{|c|}{ Riwayat Hipertensi } \\
\hline Tidak & 40 & 97,6 & 1 & 2,4 & 41 & 100 & \multirow{2}{*}{0,000} & 88 \\
\hline $\mathrm{Ya}$ & 10 & 31,3 & 22 & 68,8 & 32 & 100 & & $(10,5-733)$ \\
\hline
\end{tabular}

(C) 2021 Jurnal Mutiara Ners. This is an open accessarticleunder the CC BY-SA license Website : http://e-journal.sari-mutiara.ac.id/index.php/NERS/index 
Tabel 3 memperlihatkan bahwa usia responden yang berada pada rentang usia tidak beresiko (usia 20-35 tahun), sebagian besar mengalami pre eklamsia ringan (PER) sebanyak 47 responden $(88,7 \%)$. Sedangkan, responden yang berada pada rentang usia beresiko (usia $<20$ tahun dan $>35$ tahun) sebagian besar sebanyak 17 responden $(85 \%)$ mengalami pre eklamsia berat (PEB). Hasil analisa statistic dengan menggunakan Chi Square Test didapatkan $P$ Valuesebesar $0,000<0,05$, dengan demikian dapat disimpulkan bahwa adahubungan yang signifikan antara usia ibu hamil dengan klasifikasi pre eklamsia. Selanjutnya terlihat pula bahwa ibu hamil yang berada pada rentang usia beresiko yaitu $<20$ tahun dan >35 tahun memiliki 44 kali peluang lebih beresiko mengalami pre eklamsia berat dibandingkan dengan ibu hamil yang berada pada rentang usia tidak beresiko $(\mathrm{OR}=44,3)$.

Keterkaitan paritas dengan kejadian pre eklampsi terlihat bahwa responden yang berstatus primigravida ataupun multigravida sebagian besar mengalami pre eklamsia ringan (PER) sebanyak $83,3 \%$ pada primigravida dan $58,1 \%$ pada multigravida. Berdasarkan hasil analisa statistik dengan menggunakan Chi Square Test didapatkan $P$ Value sebesar $0,023<$ 0,05, dengan demikian dapat disimpulkan bahwa ada hubungan yang signifikan antara paritas dengan klasifikasi pre eklamsia. Padapenelitian ini, Ibu hamil yang berstatus multigravida memiliki peluang 3 kali lebih beresiko mengalami pre eklamsia berat dibandingkan dengan ibu hamil yang berstatus primigravida $(\mathrm{OR}=3,6)$.

Selanjutnya dapat dilihat bahwa semua responden yang berpendidikan rendah $(67,7 \%)$ dan tinggi (69\%) sebagian besar mengalami pre eklamsia ringan (PER). Berdasarkan hasil analisa statistik didapatkan $P$ Value sebesar 0,906 > 0,05, dengan demikian dapat disimpulkan bahwa tidak ada hubungan signifikan antara pendidikan dengan klasifikasi pre eklamsia.

Pada variabel pekerjaan yang tampak pada table diatas terlihat bahwa responden yang tidak bekerja $(65,7 \%)$ maupun yang bekerja $(71,1 \%)$ mayoritas mengalami pre eklamsia ringan (PER). Berdasarkan hasil analisa statistik didapatkan $P$ Value sebesar 0,624>0,05, dengan demikian dapat disimpulkan bahwa tidak ada hubungan yang signifikan antara pekerjaan dengan klasifikasi pre eklamsia.

Kajian terhadap riwayat hypertensi dari responden didapatkan data responden yang tidak memiliki riwayat hipertensi sebelumnya mayoritas $(97,6 \%)$ mengalami pre eklamsia ringan (PER), sedangkan pada responden yang memiliki riwayat hipertensi sebelumnya mayoritas $(68,8 \%)$ mengalami pre eklamsia berat (PEB). Berdasarkan hasil analisa statistik dengan menggunakan Chi Square Test didapatkan $P$ Value sebesar $0,000<0,05$, dengan demikian dapat disimpulkan bahwa adahubungan yang signifikan antara riwayat hipertensi dengan klasifikasi pre eklamsia. Ibu hamil yang memiliki riwayat hipertensi memiliki peluang 88 kali lebih beresiko mengalami pre eklamsia berat dibandingkan yang tidak memiliki riwayat hipertensi $(\mathrm{OR}=88)$.

\section{PEMBAHASAN}

Hasil penelitian memperlihatkan bahwa usia tidak berisiko mayoritas $(88,7 \%)$ mengalami pre eklamsia ringan (PER) dan usia berisiko mayoritas $(85 \%)$ mengalami pre 
eklamsia berat (PEB). Penelitian ini sejalan dengan penelitian Khuzaiyah et al, (2016) dimana dalam penelitiannya ditemukan $68,8 \%$ ibu hamil dengan preeklamsia terjadi pada usia 20-35 tahun. Faktor usia merupakan salah satu penyebab terjadinya pre-eklamsia, dimana pasien-pasien yang beresiko preeklamsia yaitu ibu dengan usia kurang dari 20 tahun atau lebih dari 35 tahun (Bobak, L, 2012; Ahmed, et al, 2018).

Pada usia kurang dari 20 tahun secara fisik organ reproduksi masih belum optimal untuk menerima suatu proses kehamilan, hal tersebut memungkinan terjadinya gangguan kehamilan yaitu preeeklamsia. Secara psikologi pada usia kurang dari 20 tahun juga perlu dipertimbangkan bagaimana kesiapan seorang wanita untuk menjadi seorang ibu atau perubahan peran diusia yang masih terbilang belia. Ketidaksiapan perubahan peran juga dukungan yang tidak optimal terhadap ibu akan memberikan tekanan yang dapat meningkatkan terjadinya preeklamsia.

Demikian pula dengan usia ibu yang lebih dari 35 tahun yang mengalami kehamilan, dimana secara fisiologi dan psikis biasanya tingkat kecemasan ibu lebih tinggi dalam proses kehamilan maupun persalinan sehingga hal ini memberi dampak kemungkinan ibu mengalami stres saat kehamilan yang memicu terjadinya preeklamsia.

Pada variabel paritas, didapatkan hasil yang signifikan antara paritas dengan klasifikasi pre eklamsia serta didapatkan hasil bahwa ibu dengan multigravida memiliki risiko 3 kali lebih tinggi untuk mengalami pre eklamsia berat dibandingkan dengan ibu primipara $(\mathrm{OR}=3,6)$. Khuzaiyah (2016) mengatakan bahwa paritas salah satu faktor yang turut mempengaruhi klasifikasi dari pre eklamsia. Demikian pula dengan Ramie \& Fahreza (2018); Novianti (2016) yang mengatakan ada hubungan antara paritas dengan angka kajadianpre ekalmsia. Dimana paritas kehamilan yang berulang pada wanita (multigravida) akan memberikanresiko kehamilan yang salah satunya adalah preeklamsia. Adaptasi tubuh ibu multigravida pada perubahan dinding rahim (uterus) yang lebih lemah dibandingkan ibu primigravida akibat kehamilan berulang sehingga penurunan aliran darah dalam tubuh seorang ibu yang berdampak kerusakan endotel pembuluh darah yang mengakibatkan terjadinya preeklamsia. Pada variabel pendidikan didapatkan bahwa responden yang berpendidikan rendah ataupun tinggi mayoritas mengalami pre eklamsia ringan (PER) dan hasil menunjukkan tidak ada hubungan antara pendidikan dengan klasifikasi pre eklamsia.

Hasil penelitian ini tidak sejalan dengan penelitian yang dihasilkan Rohani et al (2019) dan Tolinggi \& Nuryani (2018) yang mengatakan ada hubungan bermakna atara pendidikan dengan kejadian pre eklamsia. Tingkat pendidikan seseorang dapat mempengaruhi dalam menerima suatu informasi (daya tangkap) dan juga dalam mengambil keputusan. Dengan harapan semakin tinggi tingkat pendidikan seseorang, maka pola pikir seseorang pun semakin matang juga memiliki usaha untuk mencari informasi dari berbagai sumber dengan kecanggihan tekhnologi saat ini terutama mengenai kesehatan.

Kajian pada variabel pekerjaan memperlihatkan tidak ada hubungan antara pekerjaan dengan klasifikasi pre eklamsia. Pada penelitian ini, responden yang bekerja maupun tidak 
bekerja mayoritas mengalami pre eklamsia ringan. Penelitian ini bertentangan dengan Putriana \& Yenie (2019) yang mengungkapkan status pekerjaan ibu ada hubungan dengan kejadian preeklamsia ( $p$ value 0,014). Pekerjaan bagi ibu hamil tidak selalu memberikan dampak buruk terhadap kesehatan ibu, akan tetapi dengan menjaga kondisi tubuh yang terhindar dari stres fisik (kelelahan bekerja) maupun psikologis mampu membawa ibu melewati masa kehamilan dengan tetap sehat. Ibu hamil juga dianjurkan untuk menjalani kehamilan dengan perasaan senang dengan tidak menjadi stres atau cemas berlebihan dan juga mampu menjaga pola hidup sehat dalam kehidupan sehari-hari.

Adanya riwayat hypertensi pada ibu hamil memiliki hubungan yang signifikan dengan kleasifikasi pre eklamsi ( $p$ value: 0.000). Penelitian ini juga memperlihatkan bahwa ibu hamil yang memiliki riwayat hipertensi akan memiliki peluang 88 kali lebih beresiko mengalami pre eklamsia berat dibandingkan ibu hamil yang tidak memiliki riwayat hipertensi $(\mathrm{OR}=88)$.

Penelitian ini sejalan dengan Harun dkk (2019), Kurniawati et al, (2019) dan Tessema et al, (2015) yang berpendapat ada hubungan antara riwayat hipertensi dengan kejadian preeklmasia. Riwayat hipertensi yang dimiliki oleh ibu hamil menjadi salah satu faktor predisposisi terjadi berat ringannya preeklamsia. Dimanadengan memiliki riwayat hipertensi dan juga bertambahnya beban kerja organ selama masa kehamilan dapat meningkatkan tekanan darah yang bila tidak ditanggani dengan biak menjadi preeklamsia ringan atau berat sampai eklamsia. Wanita hamil dengan pre eklamsia cenderung memiliki perilaku kesehatan yang lebih buruk dibandingkan wanita hamil yang tidak mengerti tentang preeklamsia, sehingga sangat penting bagi wanita hamil dengan risiko pre eklamsia untuk menjaga perilaku hidup yang sehat (Iqomatulhaq et al, 2018).

Preeklamsia merupakan

komplikasi kehamilan yang berkelanjutan, diharapkan dengan antenatal care (ANC) yang teratur mencegah perkembangan preeklamsia atau bisa juga dapat mendeteksi lebih dini diagnosa preeklamsia sehingga dapat mengurangi bahaya yang selanjutnya. Demikian pula dengan ketelitian dan pengawasan petugas kesehatan dalam menemukan tandatanda dini preeklamsia dapat segera memberikan penanganan yang sesuai (Sabar et al, 2018)

\section{SIMPULAN}

Dari hasil penelitian ini dapat disimpulkan bahwa ada hubungan bermakna antara usia ibu hamil, paritas, dan riwayat hipertensi dengan klasifikasi pre eklamsia serta tidak ada hubungan bermakna antara pendidikan dan pekerjaan dengan klasifikasi pre eklamsia.

Diharapkan peran perawat untuk dapat mengidentifikasi tanda gejala pre eklamsia serta dapat memberikan edukasi dan informasi sebagai bentuk dari upaya preventif, promotifkesehatan bagi ibu selama masakehamilan. Selain itu, berkolaborasi dengan dokter dalam memonitor lebih ketat kondisi ibu selama kehamilan guna meningkatkan asuhan yang berfokus pada pasien.

\section{REFERENSI}

Ahmed, E. M., Hassanen, R. H., Abbas, A. M., \& Kalaf, S. A. (2018). Predict Risk Factors ofPreeclampsia Among Pregnant Women Attended Antenatal Clinic 
at Assiut University Hospital. Assiut Scientific Nursing Journal, 6(14), 145-156.

Bobak, Lowdermilk. (2012). KeperawatanMaternitas. Jakarta: EGC

Departemen Kesehatan RI. Laporan Hasil Riset Kesehatan Dasar (RISKESDAS) Indonesia Tahun 2007. Jakarta; Departemen Kesehatan RI ; 2008

Fatkhiyah N., Kodiyah, Masturoh. (2015). Determinan maternal kejadian preeklamsia. Jurnal Keperawatan Soedirman, Volume 11, No.1, Maret 2016

Harun, Ayatullah.,dkk. (2019). Faktor yang Berhubungan Terhadap Kejadian Preeklamsia di RSUD Syekh Yusuf Gowa Tahun 2019. Vol 3, No 1, September 2019, p-ISSN: 2597-7989, e-ISSN: 2684-8821.

Iqomatulhaq, Ermiati, Solehati Tetti. (2018). Healthy Life Behavior in Pregnancy Women with Risk of Preeclampsia in The PHC of Cigraviday Bandung District. JMCRH: Vol. 2 Issue 1

Khuzaiyah, S., Anies, A., \& Wahyuni, S. (2016). Karakteristik Ibu Hamil Preeklampsia. Jurnal miah kesehatan, 9(2), 97065.

Kurniawati, D., Septiyono, E. A., Juliningrum, P. P., \& Rahmawati, I. (2019). Analysis Characteristics of Pregnant Mother With Preeclampsia in Agronursing Area. Journal Of Nursing Practice, 3(1), 33-38.

Leveno, Kenneth. (2015). Manual komplikasi kehamilan Williams. Jakarta:EGC

Machmudah. (2015). Penerapan Model Konsep Need For Help dan Self Care pada Asuhan JeperawatanIbu Pre Eklamsia Berat dengan Terminasi Kehamilan. Jurnal
Keperawatan Maternitas. Vol 3, No.1, Mei 2015; 16-26

Novianti, H. (2016). Pengaruh Usia dan Paritas terhadap Kejadian Pre Eklampsia di RSUD Sidoarjo. Journal of Health Sciences, 9(1).

Pratamaningtyas,Susanti., Niluh Novita. (2016). Hubungan Obesitas Dengan Klasifikasi Preeklamsia Di Puskesmas Ngasem Kabupaten Kediri Tahun 2016. Jurnal Kesehatan Ibu dan Anak vol. 3 No. 2, Pebruari 2018:12 - 21.

Purde, M. T., Baumann, M. U., Wiedemann, U., Nydegger, U. E., Risch, L., Surbek, D., \& Risch, M. (2015). Incidence of preeclampsia in pregnant Swiss women. Swiss medical weekly, 145(w14175), w14175.

Putriana, Y., \& Yenie, H. (2019). Faktor-Faktor yang Berhubungan dengan Kejadian Pre Eklamsia pada Sebuah Rumah Sakit di Provinsi Lampung. Jurnal Ilmiah Keperawatan Sai Betik, 15(1), 31$42 .$.

Ramie, A., \& Fahreza, F. (2018). Riwayat Keluarga Preeklampsia Meningkatkan Kejadian Preeklampsia. Jurnal Citra Keperawatan, 6(2), 35-51.

Rohani, S., Wahyuni, R., \& Veronica, S. Y. (2019). Faktor-Faktor yang Berhubungan dengan Kejadian Pre Eklamsia Berat di Rumah Sakit Umum Pringsewu. Wellness And Healthy Magazine, 1(1), 77-85.

Rumjati, Sri Wahyuni. (2012). Gambaran tingkat pendidikandan Usia Ibu Hamil Dengan Pengetahuan Tentang Bahaya Preeklamsia Berat. Jurnal Kesehatan Abdurahman palembang, Vol.1 No.1 Maret 2012. 
Sabar, E., Setyawati, A., \& Emaliyawati, E. (2018). Foot Massage Modification to Reduce Blood Pressure in Pregnant Woman with Preeclampsia.Jurnal Keperawatan Padjadjaran,6(2).

Sirait, Anna Maria. (2012). Prevalensi Hipertensi Pada Kehamilan di Indonesia dan Berbagai Faktoryang Berhubungan dengan (Riset Kesehatan Dasar 2007).

Sukarni, I.K danWahyu.(2013). Buku Ajar Keperawatan Maternitas. Yogyakarta:NuhaMedika

Tessema, G. A., Tekeste, A., \& Ayele, T. A. (2015). Preeclampsia and associated factors among pregnant women attending antenatal care in Dessie referral hospital, Northeast Ethiopia: a hospital-based study. $B M C$ pregnancy and childbirth, 15(1), 1-7.

Tolinggi, S., Mantualangi, K., \& Nuryani, N. (2018). Kejadian Preeklampsia dan Faktor Risiko yang

mempengaruhinya. Gorontalo Journal of Public Health, 1(2), 8591.

Wawan, A dan M. Dewi. (2016).

Pengetahuan, Sikap dan Perilaku Manusia. $\quad$ Yogyakarta:

Nuha Medika

Wiknjosastro. (2010). Buku Panduan Praktis Pelayanan Kesehatan Maternal Dan Neonatal.Edisi 1 Cet.12 Jakarta: BinaPusaka Yuniarti, Siswari. (2019). Faktor Yang Berhubungan Dengan Kejadian Preeklamsia Di Rumah Sakit Umum Haji Surabaya. Semnakes.unipa.ac.idISBN:

978-602-5793-65-3.

World Health Organization.(2014).

Maternal and

Reproductive Health. WHO Press:

Genewa 